\title{
Efforts to Encourage Interest in Covid-19 Vaccination to the Community of Rw 01 Cibodas Baru Village, Tangerang City
}

\author{
Belardo Prasetya Mega Jaya, ${ }^{1 *}$, Annida Dwi Agustin², Fikry Nurhayadi ${ }^{3}$, Rafdi Altaf ${ }^{4}$, \\ Muhammad Hasyim Abdullah' ${ }^{5}$, Aulia Rusdiana ${ }^{6}$, Muhammad Ridwan ${ }^{7}$, Muhayaroh ${ }^{8}$ \\ ${ }^{1 * 2}$, Faculty of Law, University of Sultan Ageng Tirtayasa \\ ${ }^{2,3}$ Faculty of Engineering, University of Sultan Ageng Tirtayasa \\ $4,5,6,7,8$ Faculty of Teacher Training and Education, University of Sultan Ageng Tirtayasa \\ belardoprasetya@untirta.ac.id ${ }^{1^{*}}$
}

\begin{abstract}
Abstrak
Indonesia merupakan salah satu negara dengan tingkat penyebaran Covid-19 tertinggi di Asia. Vaksinasi ini merupakan salah satu upaya pemerintah Indonesia untuk memerangi pandemi Covid-19. Minimnya pengetahuan masyarakat tentang vaksin Covid-19 menjadi salah satu kendalanya. Dalam Kuliah Kerja Mahasiswa Tematik Universitas Sultan Ageng Tirtayasa tahun 2021, Kelompok 96 mengadakan program sosialisasi vaksinasi dalam bentuk webinar. Tujuannya untuk meningkatkan animo masyarakat di RW 01 Kelurahan Cibodas Baru Kota Tangerang untuk berpartisipasi dalam vaksinasi Covid-19. Metode yang digunakan adalah penelitian kuantitatif dengan menggunakan kuesioner dan menampilkan perbandingan peserta vaksinasi. Berdasarkan hasil sosialisasi kepada masyarakat mengalami peningkatan minat untuk mengikuti vaksinasi. Hal ini terlihat dari persentase masyarakat yang mengikuti kegiatan vaksinasi Covid-19 pada JuliAgustus 2021 sebesar 91,97\%.
\end{abstract}

Kata kunci: Covid-19; Vaksinasi; Sosialisasi, Kuliah Kerja Mahasiswa

\begin{abstract}
Indonesia is one of countries that has the highest rate of spread of Covid-19 in Asia. The vaccination is one of the Indonesian government's efforts to fight the Covid-19 pandemic. The lack of public knowledge about the Covid-19 vaccine is become the one of obstacle. In the Thematic Student Work Lecture of Sultan Ageng Tirtayasa University in 2021, group 96 held a vaccination socialization program in the form of a webinar. The purpose is to increase the interest of the community in RW 01 Cibodas Baru Village, Tangerang City to participate in Covid-19 vaccination. The method used is a quantitative research using a questionnaire and displaying a comparison of vaccination participants. Based on the results the outreach to the community experienced an increase in interest in participating in vaccination. This can be seen from percentage of people who participated in the Covid-19 vaccination activity in July-August 2021, which was $91.97 \%$.
\end{abstract}

Keywords : Covid-19; Vaccinations; Socialization; Thematic Student Work Lecture 


\section{Introduction}

Cibodas Baru Village, Cibodas District, Tangerang City, Banten with an area of 0.87 $\mathrm{km} 2$, consisting of $16 \mathrm{RW}, 96 \mathrm{RT}, \pm 5,941$ heads of family, and a population of $\pm 19,006$ people (Official Covid-19 Information Portal for Tangerang City Government, nd). The location of the area can be seen in Figure 1.

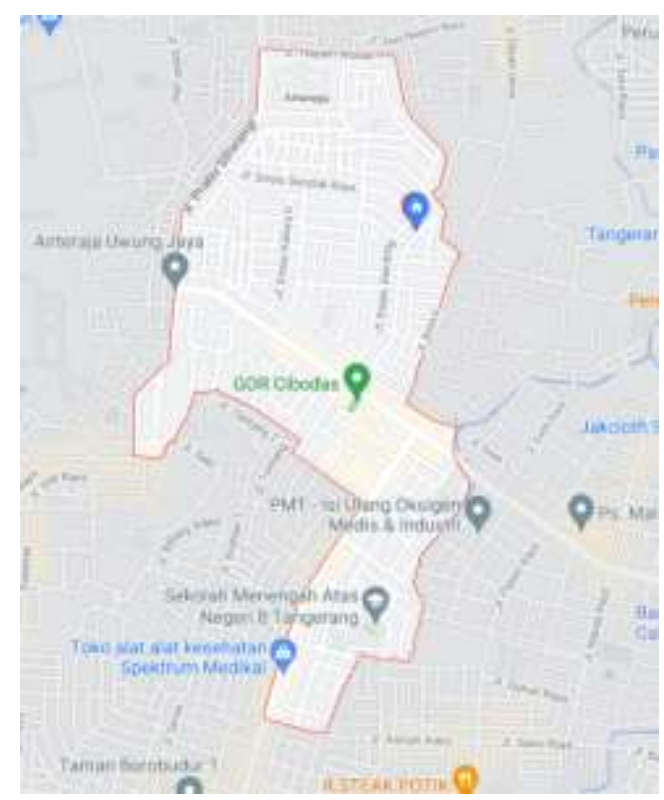

Figure 1. Location of the New Cibodas Village in Cibodas District, Tangerang City

Coronavirus disease 2019 (Covid-19) is a disease caused by the severe acute respiratory syndrome coronavirus-2 (SARS-CoV-2). According to data from the Tangerang City Health Office, Cibodas Baru Village, the total recorded positive cases of Covid-19 were 420 with a total of 8 deaths due to Covid-19 infection. The total number of patients who recovered from the corona virus was 383 people. One of the many efforts that are considered the most effective to overcome the Covid-19 pandemic is by administering a vaccine, which is still ongoing today. Vaccination is an effort by the Indonesian government in overcoming the problem of the Covid-19 pandemic

Vaccine is a biological product that contains an antigen in the form of a microorganism (in the form of dead, live attenuated, toxid, or recombinant protein) which when given will cause specific and active immunity against a particular disease or in this case an infectious disease. Covid-19. Vaccination is the administration of a vaccine that aims to cause or increase a person's immunity to a disease, so that if a patient is exposed to a certain disease at some point, the patient will not get sick or only experience mild illness and will not become a source of transmission. By carrying out appropriate or correct vaccination procedures, it is hoped that optimal immunity, safe injections and minimal post-immunization events (AEFI) will be obtained.

The Covid-19 vaccination should be carried out if the vaccine product has obtained safety assurance and has been clinically tested in an effort to reduce the risk of transmission and death as well as to support or encourage the formation of herd immunity (herd immunity). In addition, the Covid-19 vaccination activity aims to always protect and strengthen our immune system as a whole so that we can always maintain productivity in 
the community so that we can reduce the bad effects of restrictions during the pandemic, namely the social and economic impacts of the Covid-19 pandemic.

The number of vaccines currently available in Indonesia is still not enough to be given to all Indonesian people as a whole. With a limited number of vaccines, therefore priority grouping is carried out in administering the Covid-19 vaccine. Starting from health workers who are the majority of recipients, then elderly groups ( $>60$ years), public service officers, educators or teachers, market traders or other traders, religious leaders, people's representatives, state and government officials, security officers, transportation officers. , tourism sector workers, journalists and media workers as well as athletes to the general public. On February 11, 2021, the Ministry of Health has issued a circular letter number: HK.02/II/368/2021 regarding the implementation of vaccinations for the elderly, comorbid target group and Covid-19 survivors as well as delayed targets (Kemenkes RI, 2021)

Many levels of society are still hesitant in participating in Covid-19 vaccination activities because of the lack of public knowledge about the Covid-19 vaccine. Therefore, there is a need for outreach activities or outreach to the community regarding the importance of the Covid-19 vaccination program (Akbar, 2021).

On Sunday, August 1, 2021, the Health Webinar socialization program: Covid 19 Vaccine "You don't know, you're not immune" by a group of 96 Thematic KKMs at the University of Sultan Ageng Tirtayasa 2021, which is supervised by Field Supervisor Belardo Prasetya Mega Jaya, S.H., M.H. and invite Dr. dr Desdiani, Sp. P, M. K. K. as a speaker who aims to educate the people of Cibodas Baru Village about the importance of participating in Covid-19 vaccination activities.

\section{Implementation Method}

The Covid-19 vaccination activity dose 1 in the Cibodas Baru Village was carried out on 26-31 July 2021 and doses 1 and 2 were carried out on 2-14 August 2021. This study focused on residents of RW 01, Cibodas Baru Village, Cibodas District, Tangerang City, Banten. This study ran for 12 days by collecting data on vaccination participants and 1 day with the implementation of socialization techniques carried out online through the Zoom meeting video conferencing application regarding the introduction of Covid-19 vaccination. The socialization was carried out by providing an explanation of the Covid19 vaccination program to the public. The socialization of the Covid-19 vaccination aims to educate the public about Covid-19 vaccination activities so that it can increase public interest in participating in the Covid-19 vaccination. After the socialization activity, the community was given a questionnaire aimed at knowing the level of support from the community in the Covid-19 vaccination activity.

The data obtained is in the form of community data that took part in the Covid-19 vaccination before the socialization, namely on 26-31 July 2021 and after the socialization, namely on 2-14 August 2021. The next data is in the form of a questionnaire after the socialization activity regarding the introduction of the Covid-19 vaccination to The community is processed using the Excel application to be able to display data in graphical form to make it easier to read the data, also equipped with documentary evidence to strengthen the analysis and discussion of the research. 
Table 2. Socialization Questionnaire Question Form

\begin{tabular}{ll}
\hline No. & Question \\
\hline 1. & What's Your Gender? \\
2 & $\begin{array}{l}\text { Are you willing to support } \\
\text { and invite other communities } \\
\text { to support the Covid-19 } \\
\text { vaccination program? }\end{array}$
\end{tabular}

\section{Result and Discussion}

Cibodas Baru Village, Cibodas District, Tangerang City, Banten consists of 16 RW, $96 \mathrm{RT}, \pm 5,941$ heads of family, and a population of $\pm 19,006$ people (Tangerang City Government Covid-19 Information Portal, n.d.). As respondents and targets of socialization activities regarding the introduction of Covid-19 vaccination, namely people aged 18 years and over which is one of the general requirements for people who can take part in Covid-19 vaccination activities. The socialization carried out was in the form of a health webinar with the theme of the Covid-19 vaccine "Tak Kenal Maka Tak Kebal" which invited Dr. dr Desdiani, Sp. P, M. K. K. as a presenter

The number of people who filled out the questionnaire was 40 people. It consists of 23 men and 17 women as shown in Figure 2.

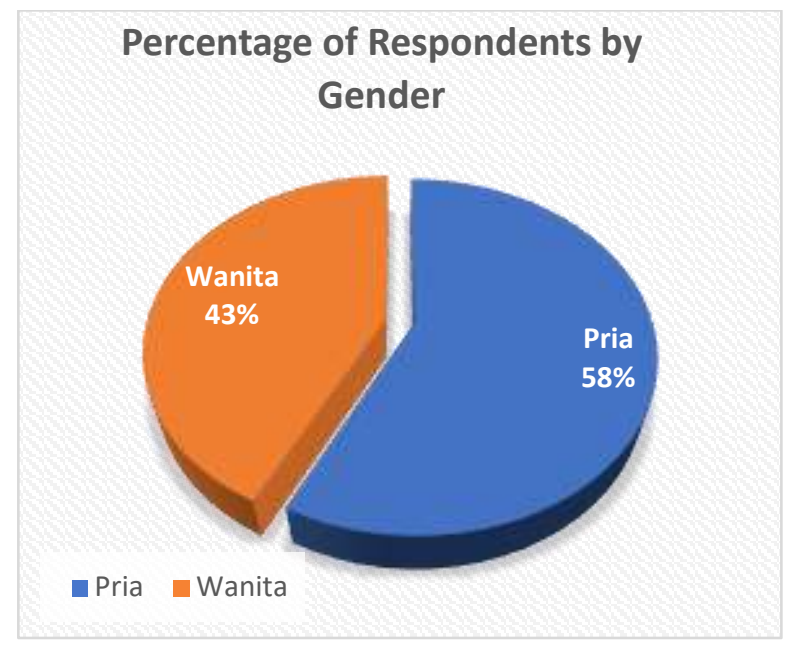

Figure 2. Percentage of Respondents by Gender

Based on the results of filling out the questionnaire conducted after the socialization activity from 40 respondents, it is known that $75 \%$ of respondents support the Covid-19 vaccination program, $2 \%$ do not support and $23 \%$ are in doubt as shown in Figure 3. 


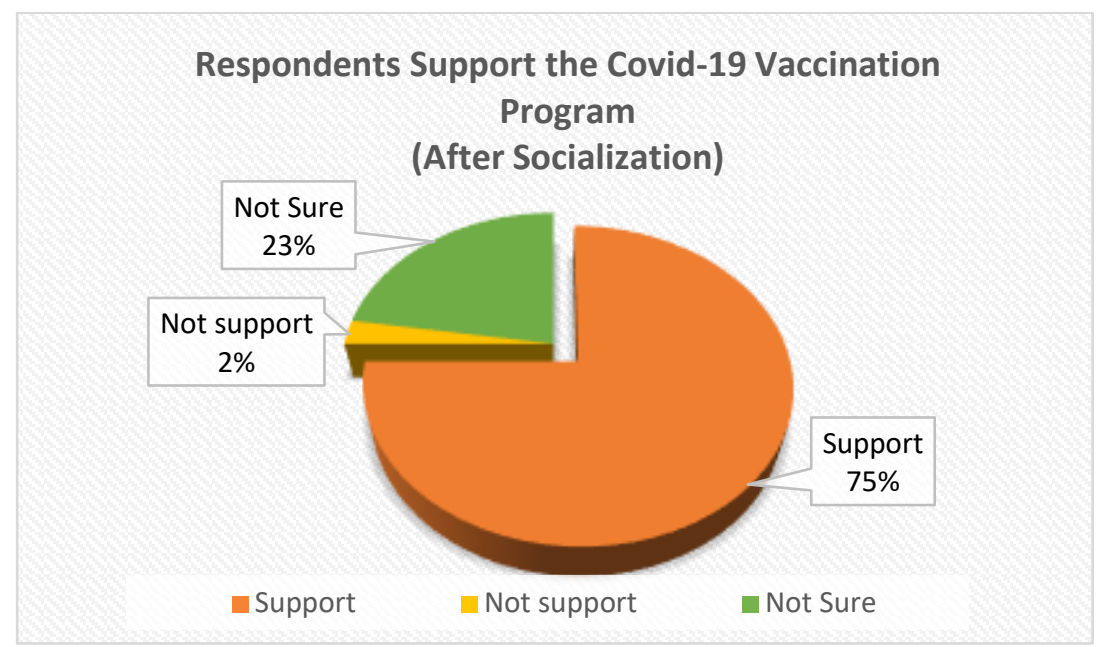

Figure 3. Percentage of Respondents who Support Covid-19 Vaccination Activities

On 26-31 July 2021 the Covid-19 vaccination activity dose 1 was carried out in the Cibodas Baru Village, Cibodas District with a quota of 1800 participants and on 2-14 August 2021 the Covid-19 vaccination activity was carried out with a quota of 1800 participants. The comparison of the number of participants in the Covid-19 vaccination activity can be seen in Figure 4.

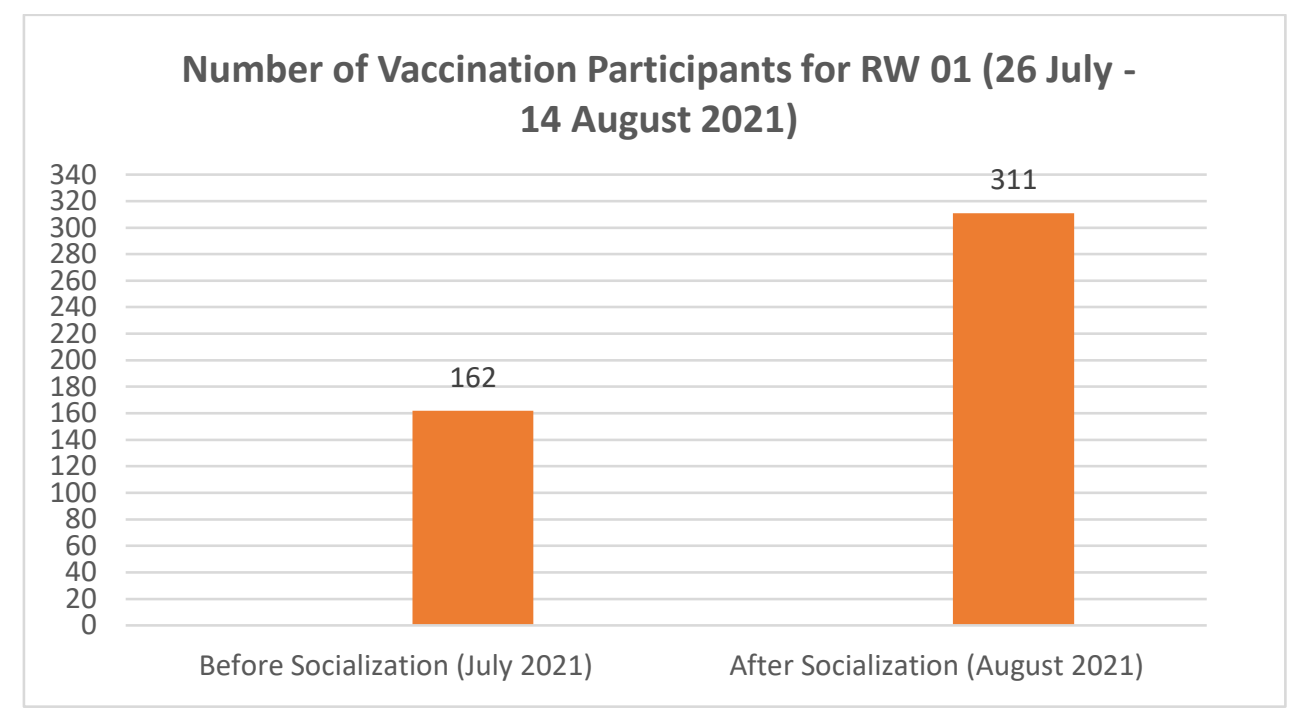

Figure 4. Data on Covid-19 Vaccination Participants

This shows that there is an increase in respondents' interest in participating in the Covid19 vaccination after the socialization activity. The increase in the number of vaccination participants occurred after socialization activities aimed at educating the wider community about vaccines and Covid-19 vaccination activities in Cibodas Baru Village. The number of vaccine participants increased by $91.97 \%$ from July 26 to August 14, 2021.

The comparison of the domicile of the Covid-19 vaccination participants based on the domicile of the RT can be seen in Figure 5. The data shows, the percentage of the number of vaccination participants is dominated by RT 02 by $27 \%$, RT 04 by $26 \%$, RT 01 by $25 \%$ and RT 03 by $22 \%$. 


\section{Percentage of Total Vaccination Participants \\ Residents of Rw 01 Cibodas Baru Village}

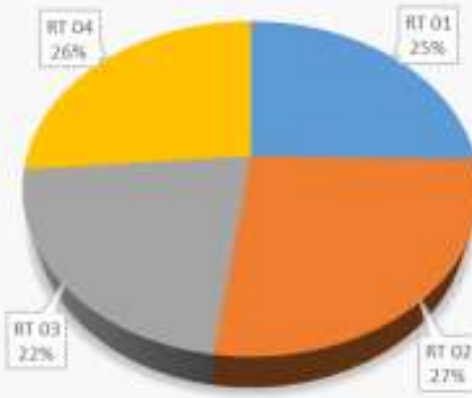

Figure 5. Percentage of Total Vaccination Participants in Rw 01 Cibodas Baru Village

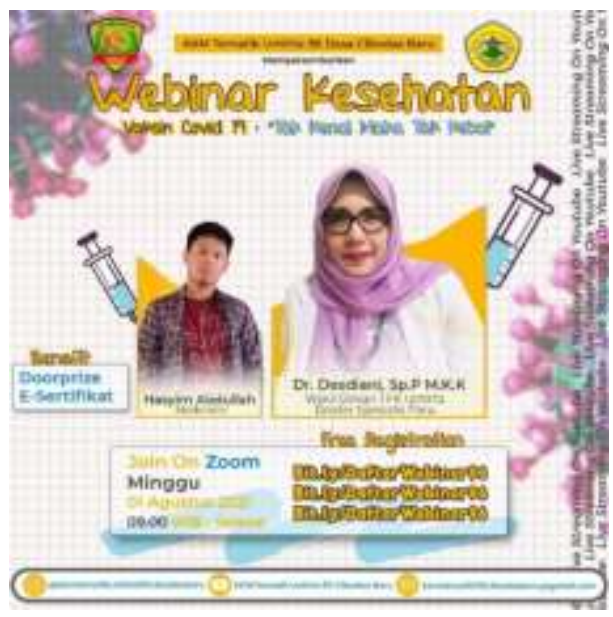

Figure 6. Health Webinar Outreach Activity Poster

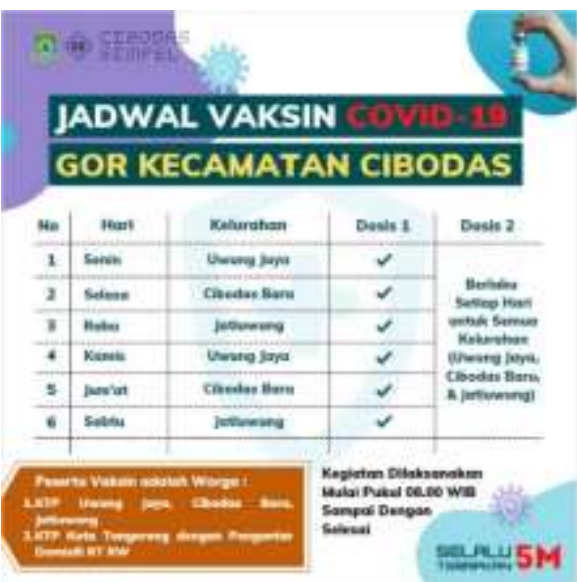

Figure 7. Information poster for the Covid-19 vaccination schedule in Cibodas Baru Village 


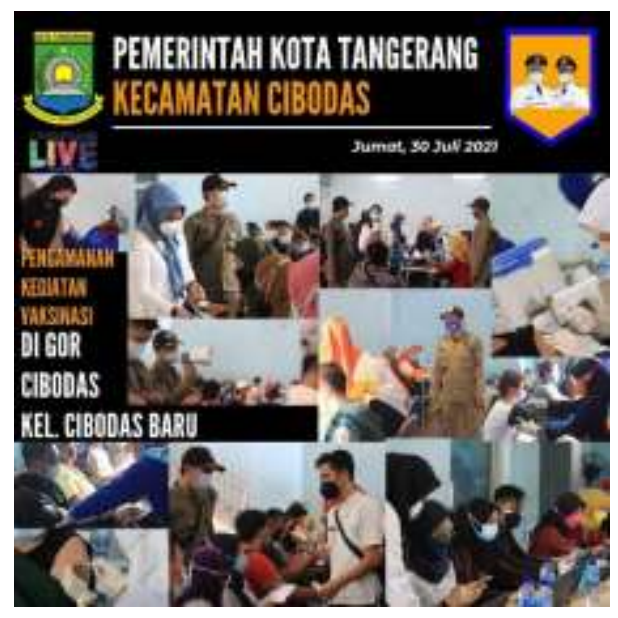

Figure 8. Documentation of Covid-19 Vaccination Activities in Cibodas District

\section{Conclusion}

The Student Work Lecture at Sultan Ageng Tirtayasa University will be held on July 16 - August 18, 2021, conducted online due to the Covid 19 pandemic and students are required to be creative in using existing technology.

In realizing the implementation of the socialization program, the group of 96 was guided by the Field Supervisor Belardo Prasetya Mega Jaya, S.H., M.H. held a health webinar with the theme of Covid-19 Vaccine: "Tak Kenal Maka Tak Kebal" inviting Dr. dr Desdiani, Sp. P, M. K. K. as a speaker targeting the community of Cibodas Baru Village, the socialization activity was carried out to educate the public to be more confident and interested in participating in the Covid-19 vaccination activity which was carried out in July-August 2021.

KKM group 96 chose online socialization activities through webinars because the counseling activities were the most effective during the pandemic while still complying with health protocols and PPKM protocols that were ongoing during the activity.

The increase in public interest in vaccines can be seen based on the results of filling out questionnaires after the socialization of the Covid-19 vaccination, with the outreach to the community, RW 01 Cibodas Baru Village, Tangerang City, Banten Province, experienced an increase in interest in participating in Covid-19 vaccination activities. This can be seen from the increase in the percentage of people who participated in the Covid19 vaccination activity in July-August 2021 , which was $91.97 \%$.

\section{Acknowledments}

This paper and the research behind it would not have been possible without the exceptional support to Mr. Belardo Prasetya Mega Jaya, S.H., M.H. as our lecturer, Dr. dr Desdiani, Sp. P, M. K. K. as a speaker who aims to educate the people of Cibodas Baru Village about the importance of participating in Covid-19 vaccination activities, Village chief of Cibodas Baru and staff. 
ISSN : 2808-2990

\section{References}

Akbar, I. (2021). Vaksinasi Covid-19 dan Kebijakan Negara: Perspektif Ekonomi Politik. Jurnal Academia Praja, 4(1), 244-254.

Arti kata vaksinasi - Kamus Besar Bahasa Indonesia (KBBI) Online. (n.d.). Retrieved August 17, 2021, from https://kbbi.web.id/vaksinasi

Ichsan, D. S., Hafid, F., Ramadhan, K., \& Taqwin, T. (2021). Determinan Kesediaan Masyarakat menerima Vaksinasi Covid-19 di Sulawesi Tengah. Poltekita : Jurnal IImu Kesehatan, 15(1), 1-11. https://doi.org/10.33860/jik.v15i1.430

Kantohe, T. V. M., Rampengan, N. H., \& Mantik, M. F. J. (2019). Faktor-Faktor Yang Memengaruhi Minat Imunisasi Measles Rubella (Mr) Di Kecamatan Malalayang, Manado. Jurnal Medik Dan Rehabilitasi, 1(3), 1-6. https://ejournal.unsrat.ac.id/index.php/jmr/article/view/22547/22238

Kemenkes RI. (2021). Question ( Faq ) Pelaksanaan Vaksinasi Covid-. 2020, 1-16. https://kesmas.kemkes.go.id/assets/uploads/contents/others/FAQ_VAKSINASI_C OVID_call_center.pdf

Kementerian Kesehatan RI, UNICEF, \& WHO. (2020). Survei penerimaan vaksin COVID-19 di Indonesia. November. https://www.unicef.org/indonesia/id/coronavirus/laporan/survei-penerimaanvaksin-covid-19-di-indonesia

Portal Resmi Informasi Covid-19 Pemerintah Kota Tangerang. (n.d.). Retrieved August 15, 2021, from https://covid19.tangerangkota.go.id/ 